\title{
HUMAN RESOURCE MANAGEMENT PRACTICES AND NIGERIAN BANKS' PERFORMANCE
}

\author{
ALASAN Ali Ibrahim ${ }^{1}$, EYANUKU Julius Paul ${ }^{2}$ \\ Faculty of Management Sciences ${ }^{1,2}$ \\ Department of Business Administration \\ National Open University of Nigeria (NOUN) \\ Emails: alasanali30@gmail.com ${ }^{1}$, jeyanuku@noun.edu.ng, jpee2002@ yahoo.com ${ }^{2}$
}

DOI: 10.36108/ljerhrm/0202.02.0190

\begin{abstract}
The importance of human resource management practices has gained acceptance and wide recognition in a cross-cultural context. Several studies, examining the procedures and practices of human resource management (HRM) and its implementation aspects have emerged, and been applied in different contexts. Achieving better employee performance has been a significant focus for both private and public organisations. Hence there is need to investigate how human resource (HR) practices impact upon organizational performance. This research focuses on three HRM variables, that is, training and development, recruitment and selection and remuneration, and the impact on organizational performance. Using a survey method, data was collected from 257 employees working in commercial banks, Ikorodu. This study analysed the data using descriptive statistics like the mean, median, maximum and standard deviation to analyse the characteristics of the variables. On the other hand, the hypotheses were tested using regression analysis. We further carry out normality test before performing regression analysis on each of the variables as shown in the following model specification, which tallies with our Research Questions, Research Objectives and Research Hypotheses. The findings revealed that training and development is positively related to organizational performance in commercial banks in Nigeria, the study concludes that, Training and Development will grants the employee's more insight and control over their jobs. Similarly, in the case of Recruitment and Selection and organizational performance, the study concludes that, employees with good motivational package have more confidence in their capabilities, thus remaining more committed to their organisations. This in-turn boosts organizational performance. Conversely, the study reported a statistical insignificant relationship between Remuneration and organizational performance in commercial banks in Nigeria
\end{abstract}

Key words: Banks, Human Resources Management, Performance,Recruitment and Selection and Remuneration, Training and Development

\section{Introduction}

In the last ten years, organizations especially in Africa have been hit with the undisputable fact that the creation of competitive advantage lies in people. Organizations have increasingly recognized the potential for their people to be a source of competitive advantage. Not too long ago, so called HR functions was the preserve of "Personnel Managers" whose duties were to recruit and select, appraise, promote and demote. These superficial duties could be performed by any manager, it therefore never seemed necessary to employ an expert in the form of a human 
resource manager let alone create a whole department dedicated to HRM. Little attention was paid to human resource management issues and its impact on organizational performance. The emphasis on traditions and socio-cultural issues injected an element of subjectivity in personnel manager's functions such as recruitment and selection, performance appraisal, promotion, demotion, and compensation (Alinno\&Igwe, 2017)

In today's competitive and rapidly changing business world, organizations especially in the service industry need to ensure maximum utilization of their resources to their own advantage; a necessity for organizational survival (Abosede, Eze\&Sowunmi, 2018)

Studies have shown that organizations can create and sustain competitive position through management of non-substitutable, rare, valuable, and inimitable internal resources (Barney, 1991). HRM has transcended from policies that gather dust to practices that produce results. Human resource management practices has the ability to create organizations that are more intelligent, flexible and competent than their rivals through the application of policies and practices that concentrate on recruiting, selecting, training skilled employees and directing theirbest efforts to cooperate within the resource bundle of the organization (El-Ghalayini, 2017).

This can potentially consolidate organization performance and create competitive advantage as a result of the historical sensitivity of human resources and the social complex of policies and practices that rivals may not be able to imitate or replicate their diversity and depth. Lately, organizations are focused on achieving superior performance through the best use of talented human resources as a strategic asset. HRM policies or strategies must now be aligned to business strategies for organizational success. No matter the amount of technology and mechanization developed, human resource remains the singular most important resource of any success-oriented organization. After all, successful businesses are built on the strengths of exceptional people (Ezejiofor, John-Akamelu\&Iyidiobi, 2017). HRM has now gained significance academically and business wise and can therefore not be relegated to the background or left in the hands of nonexperts. Attention must be paid to the human resources organizations spent considerable time and resources to select.

Achieving better corporate performance requires successful, effective and efficient exploit of organization resources and competencies in order to create and sustain competitive position locally and globally. HRM policies on selection, training and development, performance appraisal, compensation, promotion, incentives, work design, participation, involvement, communication, employment security, etc must be formulated and implemented by HRM specialist with the help of line managers to achieve the following outcomes: competence, cooperation with management, cooperation among employees, motivation, commitment, satisfaction, retention, presence, etc. (Ezejiofor, John-Akamelu\&Iyidiobi, 2017)

In fact, Ahmad and Schroeder (2003) found a positive influence of human resource management practices (information sharing, extensive training, selective hiring, compensation and incentives, status differences, employment security, and decentralization and use of teams) on organizational performance as operational performance (quality, cost reduction, flexibility, deliverability and commitment). In furtherance of this assertion, Sang (2005) also found a positive influence of human resource management practices (namely, human resource planning, staffing, incentives, appraisal, training, team work, employee participation, status difference, employment security) on organization performance. For businesses to survive, HRM should be given its rightful place 
of relevance in any organization and not left in the hands of line managers who neither have the expertise nor the time and space to carry out the enormous functions of a human resource manager. The purpose of this study is to determine the impact of HRM practices on organizational performance of some selected commercial banks in Nigeria

The primary aim of this study was to evaluate the perceptions of employees towards HRM practices and the effect of such practices on organizational performance with specific reference to some selected commercial banks in Ikorodu, Lagos State. Those objectives are to:

a. Examine the effect oftraining and development on organizational performanceof commercial banks in IkoroduLagos State.

b. Evaluate the effect of recruitment and selection on organizational performanceof commercial banks in IkoroduLagos State.

c. To determine the effect of remuneration on organizational performanceof commercial banks in IkoroduLagos State.

Attempt is made to beam searchlight on the following research questions.

a. Does trainingand development enhance performance in commercial banks in Nigeria?

b. To what extent does recruitment and selection aid performance in commercial banks in Nigeria?

c. Does good remuneration system in banking sector helps performance in commercial banks in Nigeria?

This study is geared towards testing the following hypotheses

$\mathbf{H O}_{\mathbf{1}}$ : There is no significant relationship between trainingand development and organizational performance of commercial banks in Ikorodu, Lagos State.

$\mathbf{H O}_{2}$ : There is no significance relationship between recruitmentandselectionand organizational performance

$\mathbf{H O}_{3}$ : There is no significance difference between remunerationand organizational performance

\section{Literature Review}

\section{The Concept of Human Resource Management (HRM)}

The concept of Human Resource Management was first defined by Bakke (1966) who said that the general type of activity in any function of management is to use resources effectively for an organizational objective. The function which is related to the understanding, maintenance, development, effective employment and integration of the potential in the resource of peopleshall call simply the human resources function. However, HRM emerged fully fledged later when the Michigan "matching model" (Fombrun et al, 1984) and what (Boxall 1992) calls the Harvard framework developed by Beer et al (1984) made statements on the HRM concept revealing the need to take HRM beyond just selection and compensation to broader issues that demand more comprehensive and more strategic perspective to an organization's human resources. 
The matching model of HRM held that HR systems and the organization structure should be managed in a way that is congruent with organizational strategy and further explained that there is a human resource cycle that consists of four generic processes or functions that are performed in all organizations; selection, appraisal, rewards and development. The Harvard framework is based on their belief the problems of historical personnel can only be solved when general managers develop a viewpoint of how they wish to see employees involved in and developed by the enterprise and of what HRM policies and practices may achieve those goals (Ezejiofor, JohnAkamelu\&Iyidiobi, 2017). Without either a central philosophy or a strategic vision which can be provided only by general managers - HRM is likely to remain a set of independent activities, each guided by its own practice tradition. This called for the need to have a long-term perspective in managing people and consideration of people as potential assets rather than merely a variable cost (El-Ghalayini, 2017).

\section{Concept of Organizational Performance}

The concept of performance, as it appears defined in the dictionaries of French, English and Romanian, defines more the idea of outcome, achieved goal, quality, and less the economic aspects of efficiency and effectiveness. The definition shows that the term performance was originally taken from the mechanics and sports fields, in order to subsequently be used to characterize the very good results also achieved in other fields. This means that performance is obtained only by a limited number of entities, those who get the best results. Performance cannot be associated with any result achieved, but only with a special one. What does "special" mean? In the first place, net superior to what was obtained in an earlier period, in the second place, superior to results obtained by "others" and, in a third place, different by the objectives obviously set, in a favorably acceptance (El-Ghalayini, 2017).

Currently there are a variety of definitions attributed to the concept of performance due to its subjective nature. In the literature there are many articles or studies that define the concept of performance closely related to environmental factors.

Whooley (1996) opines that performance is not an objective reality, waiting somewhere to be measured and assessed, but a socially constructed reality that exists in people's minds, if it exists somewhere. According to the author, performance may include: components, products, consequences, impact and can also be linked to economy, efficiency, effectiveness, cost effectiveness or equity. Both Lebas (1995) and Whooley (1996) consider performance as subjective and interpretative, not least, being related to the cost lines, which emphasizes the ambiguous nature of the concept. Rolstadas (1998) believes that the performance of an organizational system is a complex relationship involving seven performance criteria that must be followed: effectiveness, efficiency, quality, productivity.

\section{Recruitment and Selection}

Recruitment is the process of announcing job vacancies with a view to attracting a pool of qualified applicants to fill up vacancies in an organisation. It is regarded as a positive process (Alinno\&Igwe, 2017). Taylor (2008) posits that "recruitment involves actively soliciting applications from potential employees which is considered a positive activity that requires employers to sell themselves in 5 the relevant labour markets so as to maximize the pool of wellqualified candidates from which future employees can be chosen". According to Etomi (2002), 
recruitment is concerned with the process of attracting a sufficient number of individuals with the right profile in terms of qualifications, experience, skills and other relevant attributes to indicate their interest in working for the organisation. Recruitment is the process of generating a pool of qualified applicants for organizational jobs (Mathias \& Jackson, 2004).

Selection is the process of evaluating those who have been searched for and obtained through recruitment with a view to deciding whether they can be employed or not. It is also the process of choosing the individual or individuals who best meet the job-related criteria. "Selection is a decision-making activity: the psychological calculation of suitability" (Price, 2004). Taylor (2008) posits that "selection techniques are used to decide which of the applicants is best suited to fill the vacancy in question." Etomi (2002) opines that selection is concerned with identifying the candidates from the recruitment pool who best meet organizational requirements for employment, it is also the process through which those who are recruited are downsized to the few who are hired. According to Yoder and Staudohar (1982) "selection is the process in which candidates for employment are divided into two classes - those who will be offered employment and those who will not." While recruitment is a positive activity, by contrast selection is viewed as a negative process or activity in so far as it involves picking out the best of the bunch and turning down the rest (Taylor, 2008)

\section{Training and Development}

A formal definition of training and development is any attempt to improve current or future employee by increasing an employee's ability to perform through learning, usually by changing the employee's attitude or increasing his or her skills and knowledge (Alinno\&Igwe, 2017). While training is seen to be the process of imparting specific skills, development is said to be the learning opportunities designed to help employees grow.

According to (Armstrong, 2001) training is the formal and systematic modification of behaviour through learning which occurs as a result of education, instruction, development and planned experience. Training has the distinct role in the achievement of an organizational goal by incorporating the interests of organization and the workforce (Stone, 2002). For training to have

a better effect on performance, its design and delivery should be well executed. Training remains a vital to enhancing employee performance.

The organizational commitment or "the relative strength of an individual's identification and involvement in a particular organization" (Pool \& Pool, 2007, p. 353) depends on effective training and development programs. According to these authors, organizations demonstrating keen insight make provisions for satisfying the training needs of their current workforce. Cheng and Ho (2001) indicate that adequate training produces marked improvements in employee communication and proficiency of performances as well as extending retention time. Moreover, when programs target communication skills with co-workers, there are significant increases in profit as well as a greater number of reported positive working relationships that are formed. Also, training and education have been shown to have a significant positive effect on job involvement, job satisfaction, and organizational commitment (Karia\&Asaari, 2006). Moreover, poor performance reviews due to inadequate job training can produce employee dissatisfaction and conflict. 


\section{Concept of Compensation/Remuneration}

Compensation processes are based on compensation philosophies and strategies contained in the form of policies, guiding principles, structures and procedures which are devised and managed to provide and maintain appropriate types and levels of pay, benefits and other forms of compensation (Alinno\&Igwe, 2017). This constitutes measuring job values, designing and maintaining pay structure, paying for performance, competence and skill and providing employee benefit. However, compensation management is not just about money, it is also concerned with that non-financial compensation which provides intrinsic or extrinsic motivation (Bob, 2011). Compensation has a motivational effect and therefore implies that having a compensation structure in which the employees who perform better are paid more than the average performing employees is vital to enhancing organizational performance (Hewitt, 2009). The growing recognition and consensus that compensation promotes productivity is consistent with the early work of Peter Drucker (1956) that states "happy workers are productive workers."

\section{Theoretical Framework}

Theories on people management have been sifted, going through so many phases. From the perspectives of Taylorism, bureaucratic theory, theory $\mathrm{X}$ and theory $\mathrm{Y}$ till the breakthrough with Elton Mayo's Hawthorne experiment which began another phase of people management known as human relations. The era of personnel management surfaced which has metamorphosed into the present day Human Resource Management. Since then, HRM has captured the interest of many studies churning out loads and loads of findings that sometimes generate debates and disagreements.

\section{Theories and Perspectives of Human Resource Management}

There are several theories underpinning the practice of HRM. Two of these theories; Resourcebased View and Ability and Motivation and Opportunity theories appear to be the most popular theoretical frameworks applied in the studies that link HRM and organizational performance. The Resource-Based View (RBV) theory which blends concepts from organizational economics (Penrose, 1959) and strategic management (Barney, 1991) has it that HRM delivers added value through the strategic development of the organization's rare, valuable, imperfect to imitate and hard to substitute human resources.

The RBV establishes that competitive advantage no more lies in natural resources, technology or economies of scale, since these are easy to imitate but rather competitive advantage is dependent on the valuable, rare and costly and hard-to-imitate resources that reside with the human resources of an organization. HRMs role is to ensure that the organization's human resources meet those criteria. 13 The Ability, Motivation and Opportunity (AMO) theory also argues that the formula; Performance $=$ Ability + Motivation + Opportunity to participate provides the basis for developing HR systems that attend to employees se interests, namely their skill requirements, motivations and the quality of their job (Abosede, Eze\&Sowunmi, 2018; Appelbaum et al, 2000; Bailey et al, 2001; Boxall and Purcell, 2003). 
HRM practices therefore impact on individual performance leading to overall organizational performance if they encourage discretionary efforts, develop skills and provide with the opportunity to perform. Adding to the array of concepts and theories is the term Human Capital which was originated by Schultz (1961). Human capital is the stock of competencies, knowledge, experience, social and personal attributes including creativity and innovation, embodied in the ability to perform work so as to produce economic value. Dess and Picken (1999) assert that human capital is generally understood to consist of the individual's capabilities, knowledge, skills and experience of the company's employees and managers, as they are relevant to the task at hand, as well as the capacity to add to this reservoir of knowledge, skills and experience through individual learning. This theory is concerned with how people contribute their knowledge, skills and abilities to enhancing organizational capability and the significance of that contribution. This is rather broader in scope than human resources.

\section{Methodology}

This study adopted cross-sectional research design, which is considerably used in most organizational change and other employee attitude studies. The choice of this design is determined by four factors, namely; the purpose of the study, the type of investigation involved, and the time period over which the data was collected, and finally the type of analysis carried out. The major benefit of cross-sectional research design for this study is that the researcher would be able to collect and compare several variables in the study at the same time. Thus, the researcher intended to collect data from a sample of some selected commercial banks within Ikorodu region for the period of the study.

The population of this study covers the Managerial and non-managerial staff of commercial banks within Ikorodu region. Also, the study used the sample selection formula cited in Smith (1984) in the determination of the sample size for the study which is stated as follows:

$$
\begin{aligned}
& N \\
& n= \\
& 3+N(e)^{2} \\
& \text { Where; } \\
& \mathrm{n}=\text { Sample size } \\
& \mathrm{N}=\text { Population of the study; and } \\
& \mathrm{e}=\text { Margin of error }
\end{aligned}
$$

$3=$ Constant

After applying this formula, a representative sample size of two hundred and fifty seven (257) was chosen from a population of nine hundred and fifty (950) managerial and non-managerial staff of commercial banks within Ikorodu region with precision levels of $\pm 5 \%$ and the level of confidence is $95 \%$.Purposive sampling technique was employed.

\section{Sources and Methods of Data Collection}

This research utilized the content analysis which is a research method for making replicable and valid inferences from data to operationalize the variables. The study made use of primary sources of data in eliciting the required information needed for this study. Data was collected from primary source and secondary source. 
The method that wasused to collect primary data is questionnaire, which was administered to 275 respondents selected out of 560 staff of commercial banks within Ikorodu region, and only 250 questionnaires were completed and returned while the secondary data was acquired from published documents of such commercial banks.

\section{Measurement of Variables and Instrumentation}

In this study, questionnaire was administered to the managerial and non-managerial staff of commercial banks within Ikorodu region. A measuring instrument is said to be reliable if it is consistently reproducible. Steps were taken to ensure the reliability of the data. The Cronbach's alpha coefficient determined through STATA. Only items that returned alpha values of 0.70 and above were used.

This study analysed the data using descriptive statistics like the mean, median, maximum and standard deviation to analyse the characteristics of the variables. On the other hand, the hypotheses were tested using regression analysis. We further carry out normality test before performing regression analysis on each of the variables as shown in the following model specification, which tallies with our Research Questions, Research Objectives and Research Hypotheses. We regressed each of the variables against employee resistance using one of the main statistical tool call STATA.

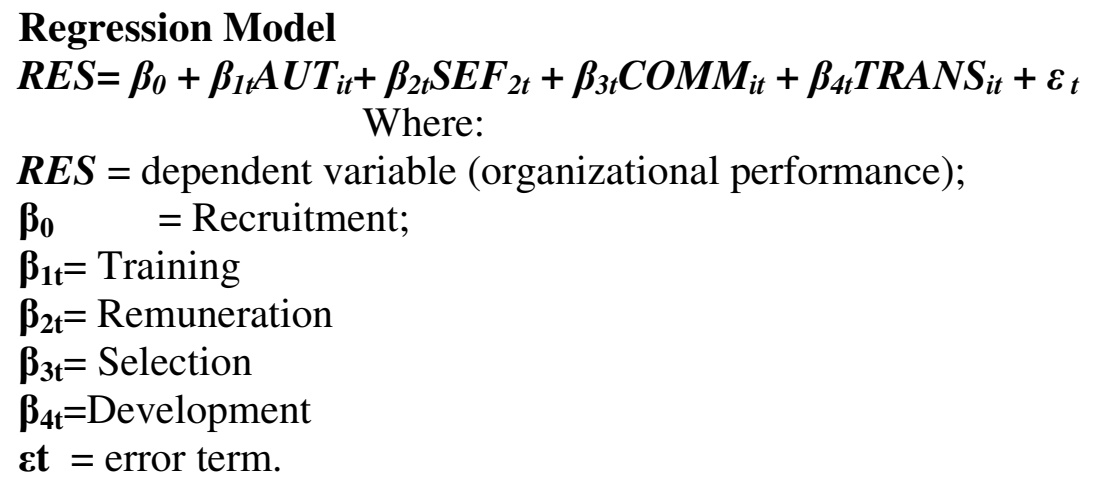

\section{Decision Rule:}

The decision to accept or reject the null hypothesis (Ho) of the statistical test was based on the 95\% confidence interval.

i. The null hypothesis is rejected if the $\mathrm{P}$ Value is at or less than 5\% (0.05) level of significance from the regression output.

ii. The null hypothesis is accepted if the P Value is more than the 5\% (0.05) level of significance from the regression output.

\section{Findings and Discussion}

The data collected for this study are presented in this section using summary statistics to describe the characteristics of the data. The summary statistics of the variables, as shown in table 4.1 show the dependent variable, "organizational performance" for all the 257 respondents. 


\section{Training and Development and Organizational Performance:}

Simple regression was conducted to examine whether training and development has significant impact on organizational performance in commercial banks, and the result is shown in table 4.1.

Table 4.1: Regression results for hypothesis one VARIABLE

\section{COEFFICIENT}

Training and Development
$\mathbf{T}$

12.44
$\mathbf{P}>\mathbf{t}$

0.000

Source: STATA13 output

The overall model was significant as F-stat $=56.52$, prob $=0.000$, suggesting that the model is fit to measure the relationship between training and development and organizational performance. The regression coefficient for the variables was significant, as $\beta=1.2071, \mathrm{p}=0.000$ indicating that training and development has a positive effect on organizational performance. This finding is significant at $5 \%$ as the p-value is 0.000 . Based on this, we do not have sufficient reasons to accept the null hypothesis and thus, we concludes that training and development has a significant effect on organizational performance.

The $\mathrm{R}^{2}$ for the regression is $48 \%$ which shows that training and development only account for about $48 \%$ of organizational performance.

\section{Recruitment and Selection and Organizational Performance}

The simple regression was used to examine whether Recruitment and Selection has significant impact on Organizational Performance in Commercial Banks, and the result is shown in table 4.2.

\section{Table 4.2: Regression results for hypothesis two \\ VARIABLE \\ Recruitment and Selection \\ COEFFICIENT \\ 0.6561 \\ $\mathbf{T}$ \\ 6.53 \\ $\mathbf{P}>\mathbf{t}$ \\ 0.000}

Source: STATA13 output

The overall model was significant as F-stat $=56.52$, prob $=0.000$, suggesting that the model is fit to measure the relationship between Recruitment and Selection and organizational performance. The regression coefficient for the variables is positive and significant, as $\beta=0.6561, p=0.000$ indicating that Recruitment and Selection has a positive organizational performance. This finding is significant at $5 \%$ as the p-value is 0.000 . Based on this, we do not have sufficient reasons to accept the null hypothesis and thus, we concludes that Recruitment and Selection has a significant effect on organizational performance.

The $\mathrm{R}^{2}$ for the regression is $48 \%$ which shows that Recruitment and Selection only account for about $48 \%$ of organizational performance.

\section{Remuneration and Organizational Performance:}


The simple regression was used to examine whether Remuneration has significant impact on Organizational Performance in commercial bank, and the result is shown in table 4.3.

\section{Table 4.3: Regression results for hypothesis three VARIABLE COEFFICIENT}

Remuneration
0.1319
$\mathbf{T}$

1.20
$\mathbf{P}>\mathbf{t}$

0.232

Source: STATA13 output

The overall model was significant as F-stat $=56.52$, prob $=0.000$, suggesting that the model is fit to measure the relationship between Remuneration and Organizational Performance. The regression coefficient for the variables is positive but insignificant, as $\beta=0.1319, p=0.232$ indicating that Remuneration has a positive impact on Organizational Performance. This finding is insignificant at $5 \%$ as the p-value is 0.232 . Based on this, we do not have sufficient reasons to reject the null hypothesis and thus, we conclude that Remuneration has no significant effect on Organizational Performance.

The $\mathrm{R}^{2}$ for the regression is $48 \%$ which shows that these leadership styles only account for about $48 \%$ of employees' performance, the remaining $52 \%$ is accounted for by other factors.

\section{Post Regression Diagnostic Test}

The test for heteroscedasticity was conducted using the Breusch-Pagan/Cook-Weisberg test for heteroscedasticity and it shows that the variables are homogenous since the hypothesis of Heteroscedasticity is rejected since the p-value is less than 5\%. Similarly, the multicollinearity test was conducted using the variance inflation factor and it shows there is no problem of multicollinearity. This confirms the claims made when presenting the data earlier in this chapter.

\section{Discussion of Findings}

The findings from the first hypothesis reveal that Training and Development positively and significantly affect organizational performance in commercial bank. The implication of these findings is that if employees are given more Training or direction over their jobs, there will be more and vice versa. This finding is in tandem with the findings in the works of Nayaab et al (2011) whose result indicated that HRM practices like training and development, employee participation in decision making was found significantly related with banks ${ }^{\text {ee }}$ performance.

Similarly, findings from the second hypothesis show that Recruitment and Selection has a significant positive effect on organizational performance in commercial banks. This implies that the higher the Recruitment, the higher the tendency of organizational performance. This finding is in tandem with the findings in the works of Boohene and Asuinura (2011) stressed that HRM practices, specifically, recruitment and selection, have positive impact on organizational performance. Also, findings from the study reveal that Remuneration has insignificant effect on organizational performance in commercial bank. This implies that when employee's are been taken care of very well, they will put more effort in their daily task in the organization.

\section{Conclusions}


Based on the findings that Training and Development is positively related to organizational performance in commercial banks in Nigeria, the study concludes that, Training and Development will grants the employee's more insight and control over their jobs.

Similarly, in the case of Recruitment and Selection and organizational performance, the study concludes that, employees with good motivational package have more confidence in their capabilities, thus remaining more committed to their organisations. This in-turn boosts organizational performance.

Conversely, the study reported a statistical insignificant relationship between Remuneration and organizational performance in commercial banks in Nigeria, and the conclusion drawn from this study is that remuneration is not a key motivational factor in an organization and thus other motivational packages should be employed alongside with motivation.

\section{References}

Abosede, A.J., Eze, B.U., \&Sowunmi, M.F. (2018). Human resource management and banks' performance in Nigeria. Izvestiya Journal of Varna University of Economics, 62(2), 7084.

Ahmad, O. \& Schroeder, R. (2003). The Impact HRM Practices on Operational Performance: Recognizing Country and Industry Differences. Journal of Operations Management, 21, $19-43$.

Al-Ahmadi. H, (2009). Factors Affecting Performance of Hospital Nurses in Riyadh Region, Saudi Arabia. International Journal of Health Care Quality Assurance, 22 (1), 40 - 54.

Alinno, F.C., \&Igwe, N.N. (2017). Proactive human resource management and the performance of the privatized organizations: Evidence from selected Nigerian organizations. European journal of business and social sciences, 6(1), 77-98.

Apostolou, A (2000). Employee InvolvementDissemination of Innovation and Knowledge Management Techniques. Technical University of Crete.

Appelbaum, E., Bailey T., Berg P., \& Kalleberg A. (2000). Manufacturing Advantage. Why High Performance Work Systems Pay Off. Itacha, Cornell University Press Armstrong, M. (1987) Human Resource Management: A Case of the Emperor's New Clothes? Personnel Management, 19(8), 30-35.

Armstrong, M. (2006).Human Resource Management Practice:A Guide To People Management. London: Kogan Page Publishers.

Armstrong, M. (2010).Essential Human resource Management Practice:A Guide to People Management. London: Kogan Page Publishers

Bakke, E. W. (1966) .Bonds of Organization: An appraisal of corporate human relations. Archon: Hamden.

Banker, R.D., Lee,S.Y\& Poitter,G. (1996). A Field Study of the Impact of A Performance-Based Incentive Plan. Journal of Accounting and Economics 21 (April): 195-226 Barney J 
(1991) Firm Resources and Sustained Competitive Advantage. Journal of Management. 17(1), 99-120.

Batt, R. (2002). Managing Customer Services: Human Resource Practices, Quit Rates and Sales Growth.Academy of Management Journal, 45(3), 113-127.

Beer, M., Spector, B., Lawrence, P.R., Quinn Mills, D. \& Walton, R.E. (1984).Human Resource Management. New York: Free Press.

Bjookman, I., \& Fey, C. F. (2000). The Effects of HRM Practices on MNC Subsidiary Performance in Russia. SSE/EPI Working Paper Series in Business Administration, NO.6.

Bob, N. (2001). Making employees suggestions Count. Journal of Personnel Management 17,20-41.

Boohene R, Asuinura E (2011). The Effect of Human Resource Management Practices on Corporate Performance: A Study of Graphic Communications Group Limited. Int. Bus. Res. J. 4(1), 266-272.

Boselie, P., Dietz, G. \& Boon, C. (2005). Commonalities and contradictions in HRM and performance research. Human Resource Management Journal, 15(3), 67-94.

Boselie, P., Hesselink, M., \&Wiele, T.V (2002). Empirical evidence for the relationship between customer satisfaction and business performance. Managing Service Quality, 12(3),184193.

Boxall, P., \& Purcell, J. (2008).Strategy and Human Resource Management. Basingstoke, Palgrave Macmillan.

Boxall, P., \& Purcell, J. (2003).Strategy and Human Resource Management.Basingstoke and New York: Palgrave Macmillan.

Bratton, J. \& Gold. J. (2007).Human Resource Management: Theory and Practice (4th ed) London: Palgrave.

Brian H. (2000).Beyond Knowledge Management: New Ways to Work and Learn, 114-543

Brockbank, W. (1999). If HR Were Really Strategically Proactive: Present and Future Directions in $\mathrm{HR}^{\text {ee }}$ S Contribution to Competitive Advantage. Human Resource Management, 38, $337-352$

Buchanan, D. (1979). The Development of Job Design Theories and Techniques. New York: Praeger Publishers.

Buchanan, D. \&Huczynski, A., (2004).Organizational Behaviour. An Introductory Text(5 ${ }^{\text {th }}$ Ed.).Essex: Prentice Hall.

Byars, L. L. \& Rue, L. W. (2000).Human Resource Management: (6 ${ }^{\text {th }}$ Ed.).Boston: McGraw Hill.

Cappelli, P. and Neumark, D. (2001). Do High Performance Work Practices Improve Establishment-Level Outcomes? Industrial and Labor Relations Review, 54(4 ), 737-775.

Cheng E. W. L.,\& Ho D. C. K. (2001). The influence of job and career attitudes on learning motivation and transfer. Career Development International, 6, 20-27. 
Chien, M.H (2004). A Study to Improve Organizational Performance: A View From SHRM.Journal of American Academy of Business, 4, 1/2, 289.

Cully, M., WoodlS., O'Reilly, A \& Dix, G. (1999). Small Business Employment Relations in Workplace: Employee Relations Survey. London:Routledge

Daft, R.L. (2000). Organization Theory and Design(7th Ed.). South-Western College Publishing, Thompson Learning. U.S.A 115.

Dany, F., Guedri Z., \& Hatt, F. (2008). New Insights into the Link Between HRM Integration and Organizational Performance: The Moderating Role of Influence Distribution Between HRM .

Delery, J.E., \& Doty, H.D. (1996). Modes of Theorizing in Strategic Human Resource Management: Tests of Universalistic, Contingency, and Configurational Performance predictions.Academy of Management Journal, 39(4), 802-35.

Dess, G. D., \&Picken, J. C. (1999) Beyond Productivity: How Leading Companies Achieve Superior Performance By Leveraging Their Human Capital. New York: American Management Association.

Dessler, G. (2008) Human Resource Management (11 $1^{\text {th }}$ Ed.). New Jersey: Prentice Hall.

Drucker, J., White, G., Hegewisch, A., \&Mayne, L. (1996) Between hard and soft HRM: human resource management in the construction industry.Construction Management and Economics, 14, 405-416.

Dyer, L \& Reeves, T. (1995) HR strategies and firm performance: what do we know and where do we need to go. International Journal of Human Resource Management 6(3), 656-670.

El-Ghalayini, Y. (2017). Human resource management practices and organizational performance in public sector organization. Journal of business studies, 8(3), 65-80.

Fey, C. F., Bjookman, I., \&Pavlovskaya, A. (2000) The effect of human resource management practices on firm performance in Russia. International Journal of Human Resource Management, 11(1), 1-18.

Fey, C. F., Engstrom, P. \&Bjookman, I. (1999) Effective HRM practices for foreign firms in Russia. Organizational Dynamics, Autumn, 69-80.

Fiorito, J., Bozeman, D.P., Young, A. \&Meurs, J.A. (2007) Organizational commitment, human resource practices, and organizational characteristics. Journal of Managerial Issues, 19(2), 186-207.

Fombrun, C.J., Tichy, N.M., \& Devanna, M.A. (1984) Strategic Human Resource Management. New York:

Gnan, L., \&Songini, L. (2003) The Professionalization of Family Firms: The Role of Agency Cost Control Mechanisms. FBN Proceedings, 141-172.

Golhar D., and Deshpande (1997) 'HMR Practices of Large and Small Canadian Manufacturing Firms', Journal of Small Business Management, 35(3), 30- 38.

Green, W.K., Wu, C., Whitten, D., \& Medlin, B. (2006) The Impact of Strategic Human Resource Management on Firm Performance and HR Professionals; Work Attitude and 
Work Performance. International Journal of Human Resource Management, 8(3), 263276.

Guest, D. (2002) Human Resource Management, Corporate Performance and Employee wellbeing: Building the worker into Human Resource Managers.The Journal of Industrial Relations 44(3), 335-358.

Guthrie, J. (2001) 'High-involvement work practices, turnover and productivity: evidence from New Zealand ${ }^{e e}$. Academy of Management Journal,44, 180-192.

Hackett, B. (2000) Beyond Knowledge Management: New Ways To Work And Learn. The Conference Board Inc., Research Report 1262-00-RR

Heshizer, B. (1994) The impact of flexible benefit plans on job satisfaction, organizational commitment and turnover intentions. Benefits Quarterly, 4, 84-90 117

Hewitt, A. (2009) Managing performance with incentive pay, Journal of personnel Management, 7(1): 20-31

Hornsby, J. S. and D. K. Kuratko, (1990) „Human Resource Management in Small Business: Critical Issues for the 1990s', Journal of Small Business Management 28 (3) 9-18.

Huselid, M.A. (1995) The Impact of Human Resource Management Practices on Turnover, Productivity and Corporate Financial Performance.Academy of Management Journal,38: 635-670.

Hyde, Jeffrey, Richard Stup, and Lisa Holden, (2008) "The Effect of Human Resource Management Practices on Farm Profitability: An Initial Assessment." Economics Bulletin, Vol.17, No. 12 pp. 1-10 International Business Research ISSN 1913-9004 (Print) ISSN 1913-9012 (Online) International Journal of Business and Management HRM Practices and Organizational Performance: An Empirical Analysis; assessed on 22nd June, 2013

Javier (2002). A Review Paper On Organizational Culture And Organizational Performance. www.ijbssnet.com/journals

Karia, N., \&Hasmi Abu Hassan Asaari M. H. A. H. (2006). The effects of total quality management practices on employees' work-related attitudes, The TQM Magazine, 18(1) 30-43.

Katou, A.A., \&Budhwar, P.S. (2007). The effect of human resource management policies on organizational performance in Greek manufacturing firms. Thunderbird International Business Review, 49, 1-35.

Keenoy, T. (1990). HRM: a case of the wolf in sheep's clothing', Personnel Review, 19, 2: 3 - 9 Khan, M. (2010) Effects of Human Resource Management Practices on Organizational Performance - An Empirical Study of Oil and Gas Industry in Pakistan. European Journal of Economics, Finance and Administrative Sciences 24,157-175.

Klein, K. (2004). Investigating the Use of Human Resource Management Best Practice in New Zealand Firms. Ota. Management Graduates Rev. Journal, 2, 39-68. 
Kuvaas, B. (2008). An exploration of how the employee-organization relationship affects the linkage between perception of developmental human resource practices and employee outcomes. Journal of Management Studies, 45(1)1-25.

Leana, C.R., Ahlbrandt, R.S., \& Murrell, A.J. (1992). The Effects of Employee Involvement Programs on Unionized Workers' Attitudes, Perceptions, and Preferences in Decision Making. Academy of Management Journal, 35 (4), 861- 873.

Legge, K. (1995). Human Resource Management: Rhetorics and Realities. Chippenham: MacMillan Business.

Luthans, F. (2005). Managing Performance through Job Design \& Goal Setting.Organizational Behavior $\left(10^{\text {th }} \mathrm{Ed}\right.$.). 478-505. McGrawHill International Edition.

MacDuffie, J.P. (1995). Human resource bundles and manufacturing performance: Organizational logic and flexible production systems in the world auto industry. Industrial and Labor Relations Review, 48, 197-221.

Manolescu, A. (2003). Human Resource Management.( $4^{\text {th }}$ Ed.).Bucarest:The Economic Publishing House.

Matlay, H. (1999).Employee Relations in Small Firms: A Micro-Business Perspective ${ }^{\text {ee }}$ Employee Relations, Vol. 21, No.3,pp. 285-295.

Mayo, A. (1991) Managing Careers: Strategies for Organizations. London: IPM Press.

Milkovich, T. G., \& Boudreau, W. J. (1998) Human Resource Management ( $8^{\text {th }}$ Ed.).Boston: Irwin.

Nayaab, H. H., Hamid M., Naseer F., Iqbal M. (2011) “The Impact of HRM practices on the Organizational performance: The study of banking sector in Okara, Punjab Pakistan)", Interdisciplinary Journal of Contemporary Research in Business, 3(119), 661-672.

Nayab, N. \& Richter, L. (2011) The Difference Between Appraisal And Performance Management.

Ngo Hang Yue, Lau Chung Ming and Foley Sharon (2008) Strategic Human Resource Management, Firm Performance, and Employee relations climate in China.Human Resource Management, 47(1),73-90.

Opatha, H.H.D.N.P, (2002) Performance Evaluation of Human Resource, 1st Edition, pp. 2 12,170 - 183, Colombo, Sri Lanka: The Author publication.

Pareek, U. \&Rao, T.V. (2006) Designing and Managing Human Resource System, Oxford and IBH Publishing Co. Pvt. Ltd. Penrose, E. T. (1959)a.The Theory of the Growth of the Firm. Oxford: Oxford University Press.

Pfeffer, J.(1998) The Human Equation : Building Profits by Putting People First.Boston,MA:Harvard Business School Press.

Ricardo, R. \& Wade, D. (2001) Corporate Performance Management: How to Build a Better Organization Through Measurement Driven Strategies Alignment. Butterworth: Heinemann 
Richard et al. (2009) Measuring Organizational Performance: Towards Methodological Best Practice. Journal of Management, 120.

Richard, O.C., and Johnson, N.B. (2001) „Strategic Human Resource Management Effectiveness and Firm Performance, 'International Journal of Human Resource Management, 12(2), 299-310.

Saks, A. M. \&Rotman, J. L. (2006) Antecedents and consequences of employee engagement.Journal of Managerial Psychology, 21(7) 600- 619.

Salanova, M., Agut, S. \&Peiró, J.M. (2005) Linking organizational resources and work engagement to employee performance and customer loyalty: The mediation of service climate. Journal of Applied Psychology, 90(6) 1217- 1227.

Sang C (2005) Relationship between HRM Practices and the Perception of Organizational Performance, Roles of Management Style, Social Capital, and Culture: Comparison between Manufacturing Firms in Cambodia and Taiwan. Unpublished Master Thesis.National Cheng Kung University. Tainan. Taiwan.

SaxenaKarunesh\& Tiwari Pankaj (2009) A Study of HRM Practices in Selected IT Companies of India, AIMS Journal of Management, 1(3), 29-44.

Schaufeli, W. B. \& Bakker, A. B. (2004) Job demands, job resources, and their relationship with burnout and engagement: A multi-sample study. Journal of Organizational Behavior, 25, 293- 315.

Schuler, R.S. \& Jackson, S.E. (1987) Linking competitive strategies with human resource management practices, Academy of Management Executive, 1(3),207-19.

Schuler, R.S. \& MacMillan, I.C. (1984) Gaining Competitive Advantage through Human Resource Management Practices, Human Resource Management, Fall, 23(3), 241-256.

Schultz, T. W. (1961) Investment in Human Capital. The American Economic Review 1(2), 1-17 121.

Som, A. (2008) Innovative human resource management and corporate performance in the context of economic liberalization in India, The International Journal of Human Resource Management

Storey, J. (1987) 'Developments in the management of human resources: an interim report', Warwick Papers in Industrial Relations , 17, IRRU, School of Industrial and Business Studies, University of Warwick (November)

Vaughan, E. (1994) 'The trial between sense and sentiment: a reflection on the language of HRM', Journal of General Management, 19(3), 20-32.

Wagar, T. \& Rondeau, K. (2006) Retaining Employees in Small and Medium-Sized Firms: Examining the link with HRM. Journal of Applied Management and Entrepreneurship, 11(2),3-16.

Wagner, T. H., (1998) Determinants of Human Resource Management Practices in Small Firms: Some Evidence from Atlantic Canada. Journal of Small Business Management, 36, 13-23. 
Wang, Z. M. (2005) Organizational effectiveness through technology innovation and HRM strategies. International Journal of Manpower, 26(6), 481-487.

Weiss, B.T. and Hartle, F. (1998) Reengineering performance management: Breakthroughs in achieving strategy through people.The Hay Group, St. Lucie Press, Roca Raton, Florida 122.

Wiese, D.S. \& Buckley M.R. (1998) The Evaluation Of The Performance Appraisal Process. Journal of Management History, 4 (3) 233-249.

Wright, P. M., \& Snell, S. A. (1991) Toward an integrative view of strategic human resource management.Human Resource Management Review, 1, 203-225. 